\title{
Altın Fiyatını Etkileyen Faktörlerin Var Modeli İle Analizi:2005-2015 Dönemi
}

\author{
Analysis of Factors Affecting The Gold Prices Through Var Model: \\ 2005-2015 Period
}

Özge ELMASTAŞ GÜLTEKIN ${ }^{1}$, Elvan AKTÜRK HAYAT²

\begin{abstract}
ÖZET
Altın yoğun olarak tercih edilen bir yatııı aracı olmakla birlikte ekonomik istikrarsızlıklardan ve politik koşullardan kolayca etkilenmektedir. Bu çalışmada, Türkiye'de altın fiyatlarının hangi ekonomik faktörlerden etkilendiğinin zaman serisi tekniklerinden Vektör Otoregresif Modeller (VAR) kullanılarak araştııılması ve değişkenler arasındaki dinamik ve istikrarlı ilişkilerin ortaya konulması amaçlanmaktadır. Bu amaçla, 2005:01-2015:04 dönemine ait aylık değerleri ile ele alınan İstanbul Altın Borsası'nda (iAB) oluşan altın fiyatları, döviz kuru, faiz oranı, TÜFE ve BIST 100 endeksi, altının ons fiyatı ve petrol fiyatı değişkenleri durağanlık ve eşbütünleşme testleri sonucuna göre VAR modeli ile incelenmişlerdir. Analiz sonuçlarına göre, IAB altın fiyatı için gelecek dönem öngörü hata varyansı içinde en büyük paya sahip değişkenler ons fiyatı ile petrol fiyatı olurken en düşük paya sahip değişken faiz oranıdır. Ayrıca, altının ons fiyatındaki bir standart sapmalık şok $I A B$ altın fiyatı üzerinde en fazla tepkiyi yaratırken petrol fiyatındaki şok ise, döviz kuru ve ons fiyatı üzerinde tepki yaratmaktadır.
\end{abstract}

Anahtar Kelimeler: Altın fiyatları, Eşbütünleşme, Granger nedensellik testi, Vektör otoregresif (VAR) model.

\section{GiRiş}

Altın, kimyasal maddelere ve oksitlenmeye karşı dayanıklı olması, kolayca şekil verilmesi ve ısı ve elektrik iletkenliklerinin yüksek olması gibi birtakım fiziksel ve kimyasal özelliklerinden dolayı da önemli bir metaldir. Bu özelliklerinin yanı sıra bir tasarruf aracı olarak tüm dünyada kabul görmesi de altının değerini daha da arttırmaktadır.

Altın, 1870-1930 arası para sisteminin temelini oluşturmuş, Bretton-Woods Sistemi'nde (1944-1973) ise dolara konvertibilitesi tam olan bir rezerv aracı niteliği taşımıştır. 1970'lerin başından itibaren doların

\begin{abstract}
Both gold is a mostly preferred investment instrument and is easily influenced by economic instability and politic conditions. It's aimed to examine which economic factors affecting the price of gold in Turkey using the vector autoregression (VAR) models that is time series method and to reveal the dynamic and stable relations between variables. For this purpose, we obtained Borsa Istanbul (BI) gold prices, exchange rate, interest rate, consumer price index (CPI) and BIST 100 index, the ounce prices of gold and oil price variables. Monthly data between 2005:01-2015:04 has been analysed with VAR model depending on stationarity and cointegration tests. According to the results of the analyses, while the largest shares of the variables are ounce and oil prices, the lowest is interest rate in future period prediction error variance for BI gold prices. Besides, one standart deviation shock on ounce prices of gold creates the most response on $\mathrm{BI}$ gold prices and the shock on oil prices create the response on exchange rate and ounce prices.
\end{abstract}

Key Words: Gold prices, Cointegration, Granger causality test, Vector autoregressive (VAR) model.

altına konvertibilitesine son verildiğinden altının değişim aracı niteliğini yitirmesine, bireysel tasarruf aracı ve merkez bankaları rezervlerinin bir parçası olarak kullanılmasına sebep olmuştur. Finansal piyasaların hızla geliştiği 1980 ve 1990 'lı yıllarda altın yatırım cazibesini kaybetse de, 2000 'li yıllarda finansal piyasalarda gözlenen belirsizlik ortamının da etkisiyle yatırımcıların tekrar ilgisini çekmeye başlamış, özellikle küresel krizin yaşandığı dönemlerde de altın fiyatları rekor seviyelere yükselmiştir (Topçu,2010).

Günümüzde altın, enflasyona karşı korunma amaçlı kullanılmaktadır. Ayrıca, siyasi ve ekonomik 
belirsizliklerde güvenilirdir ve finansal bir yatırım aracı olma özelliğine sahiptir. Bu sebeplerle, altın merkez bankalarının rezervleri içerisinde önemli bir yere sahiptir (Taşçı,2010).

1980 'de, 1350 ton civarında olan altın üretiminin yarısından fazlası Güney Afrika, ABD, Avustralya ve Kanada tarafından üretilmekteyken, 2008 yılında yaklaşık 2300 tonluk altın üretiminin 750 tonu bu ülkeler dışındaki ülkelerce üretilmektedir. 2005 yılına kadar tüm ülkelerce üretilen altın miktarı sürekli artış eğilimi göstermektedir ancak bu yılda düşmüştür (Taşçı,2010).

Türkiye gibi gelişmekte olan ülkeler açısından da altın, yatırım araçları içerisinde önemli biryere sahiptir. Ülkemizde, 1980'li yıllarda yatırım alternatiflerinin sınırlı olması ve enflasyonun yüksek olması toplumu altına yatırım yapmaya itmiştir. Bu yüzden altın, geniş kitleleri ilgilendiren bir yatırım aracı haline gelmiştir.

Altın, hem ekonomik istikrarsızlıklardan hem de politik durumlardan kolayca etkilenmektedir ve dolayısıyla altın fiyatlarında önemli dalgalanmalar görülmektedir. Altın fiyatları piyasada arz ve talebe göre belirlenmeye başladıktan sonra hangi faktörlerin altın fiyatlarını etkilediği önem kazanmaktadır. Altının arz ve talebini etkileyen faktörlerden bazıları, döviz piyasasındaki dalgalanmalar, petrol fiyatları, enflasyon, faiz oranları, ülkelerdeki politik durum, vb. olmaktadır.

Türkiye'deki altın piyasasında, altın fiyatını belirleyen etkenler yurt dışı ve yurt içi faktörler göz önüne alınarak saptanabilir. Örneğin; petrol fiyatlarında görülen artış veya azalışlar, OPEC toplantılarında alınan üretim ile ilgili kota kararları, petrol üreticisi olan bir ülkede yaşanan siyasi karışıklıklar vb. petrol fiyatlarını etkilemekte ve böylece altının arz ve talebi bundan direkt olarak etkilenmektedir. Petrol fiyatları ile altın fiyatları arasında doğrudan bir ilişki söz konusudur. Ayrıca Avrupa borsalarındaki ons fiyatı, gerek TCMB gerekse Kapalıçarşı'daki altın tüccarlarının izlemek zorunda olduğu en önemli referanstır. Bunun yanında Dünya borsalarında her an değişikliğe uğrayan döviz kurları, tıpkı altın gibi birçok olaydan rahatlıkla etkilenebilmektedir. Özellikle ABD, Japonya, Euro bölgesi ülkeleri gibi dış ticarette söz sahibi ülkelerin ekonomilerine ilişkin açılamaları, dış ticaret verileri, enflasyon ile ilgili tahmin ve yorumları, sanayi üretimi ve tüketimi ile ilgili açıklamaları, işsizlik rakamlarındaki artış veya azalışlar, emlak fiyatlarındaki değişiklikler döviz piyasalarını doğrudan etkilemektedir (Kültürcü, 2014).

BIST 100 endeksiilealtın fiyatı arasındakiilişkinin ise negatif yönlü olduğu kabul edilmektedir. Pay senedi piyasalarının düştüğü dönemlerde yatırımcıların riski azaltmak ve piyasalardaki oynaklığa karşı kendilerini korumak amacıyla pay senedi piyasalarındaki yatırımlarını çekip altına yatırım yaptıkları ve bunun da altının fiyatını yükselttiği belirlenmiştir. Tersi durumda güvenilir piyasa oluştuğunda altındaki yatırımların pay senedi piyasalarına yöneldiği ve pay senedi fiyatlarının yükseldiği gözlemlenmiştir. Dolayısıyla kar elde etmek için piyasaların arttığı dönemde düşük fiyattan altın alınıp, piyasanın düştüğü dönemde yüksek fiyattan satma stratejileri uygulanmaktadır (Yıldız, 2014). Son olarak, altın fiyatı ile faiz oranı ve TÜFE arasında da ilişki olduğu literatür çalışmalarından ortaya çıkmaktadır (Taşçı,2010; Topçu,2010).

Bu bilgiler ışığında, bu çalışmada, döviz kuru, faiz oranı, TÜFE ve BIST 100 endeksi, altının ons fiyatı ve petrol fiyatı değişkenlerinin Türkiye'deki altın fiyatları üzerindeki etkisi VAR (Vektör OtoregresifVector Autoregressive) modeller çerçevesinde değerlendirilmiştir. Bu amaçla, Ocak 2005- Nisan 2015 dönemine ait aylık bazda elde edilen veriler (124 gözlem) kullanılarak durağanlık, eşbütünleşme ve nedensellik testleri yapılmış, VAR analizi uygulanmış ve sonuçlar yorumlanmıştır.

Çalışmanın izleyen bölümleri şu şekilde düzenlenmiştir: İkinci bölümde ilgili literatür özeti yer almaktadır. Üçüncü bölümde veri seti ve yöntem hakkında bilgi verilmiştir. Uygulamanın yer aldığı dördüncü bölümde ise değişkenlere ait özet bilgiler, VAR analizinin adımları ile analizlerden elde edilen bulgular sunulmuştur. Beşinci bölüm ise genel değerlendirme ve sonuçtan oluşmaktadır.

\section{LITERATÜR ÖZETi}

Selvanathan ve Selvanathan (1999) çalışmalarında, 1948-1994 yılları arasındaki yıllık veriler için Avustralya'daki altın fiyatları ile altın üretimi arasındaki ilişkiyi ekonometrik zaman serileri analizi ile incelemişlerdir. Çalışma sonucunda, altın fiyatlarının \%10 oranında arttığı ve sonraki 5 yıl için aynı kaldığı ve altın üretiminde ise ilk yı \%0,3, ikinci yıl \%2,2, üçüncü yıl \%7,4, dördüncü yıl \%8,9 ve beşinci yıl \%10,7'lik bir artışa sebep olduğu ortaya çıkmıştır. 
Vural (2003), 1990:01-2003:03 dönemini incelediği çalışmasında, altın fiyatları ile döviz piyasası, hisse senedi piyasası, faiz oranları, petrol, gümüş ve bakır fiyatları arasındaki ilişkiyi tespit etmek amacıyla ekonometrik bir model ile araştırma yapılmıştır. Analiz sonucunda, kısa dönem için altın fiyatlarındaki değişikliklerin \%40'ı döviz, hisse senedi, gümüş fiyatı ve petrol fiyatıyla açıklanabilirken, bakır fiyatındaki ve faiz oranındaki değişikliklerin altın fiyatını etkilemediği ortaya çıkmıştır.

Gökdemir ve Ergün (2007) çalışmalarında, özellikle son otuz yılda dünyada ortaya çıkan ekonomikpolitik istikrarsızıkların altın fiyatını nasıl etkilediği açıklanmış ve altın fiyatındaki yükselişlerin Türkiye'nin altın ticaretine olan etkileri incelenmiştir. Çalışmada, altın fiyatlarında ortaya çıkan istikrarsızlıkların, Türkiye'nin altın ithalat ve ihracatını önemli oranlarda etkilediği sonucuna varılmıştır.

Poyraz ve Didin'in (2008), 1996-2005 dönemini ele aldığı çalışmalarında, Türkiye altın fiyatlarının döviz kuru, döviz rezervi ve petrol fiyatlarındaki değişime ne derece bağımlı olduğu çoklu faktör modeli yardımıyla tespit edilmeye çalışılmış̧ır. Analiz sonuçlarına göre, altın fiyatları üzerinde döviz kurunun, döviz rezervlerinin ve petrol fiyatlarının etkili olduğu ortaya çıkmıştır.

Soytas vd. (2009) çalışmalarında, 2 Mayıs 20031 Mart 2007 tarihleri arasındaki günlük veriler için, dünya petrol fiyatı ile spot altın ve gümüş fiyatları, TL/ ABD Dolar'ı döviz kuru ve Türkiye faiz oranı arasındaki uzun ve kısa dönem dinamik ilişkileri araştırmışlardır. Analiz sonucunda, petrol fiyatının altın fiyatı üzerinde fazla bir etkisinin olmadığı gözlenmiştir.

Duyar (2010) çalışmasında, dünya altın arzını etkileyen faktörler ve bu faktörlerin oluşan fiyatlar üzerinde nasıl bir etki yarattığını incelemiştir. Ayrıca, özellikle dünya altın arzı, altın fiyatları, altın üretim maliyetleri ve firmaların üretim - fiyat ilişkisindeki durumları analiz edilmiştir. Bununla birlikte altın arzını etkileyen başıca faktörler arasında olan madencilik şirketlerinin madenlerdeki verimi artırmaları, madencilik şirketlerinin birleşmesi ve yeni maden yatakları arama gibi faktörlerin altın arzındaki önemine vurgu yapılmıştır.

Taşçı́nın (2010), 1994-2009 dönemini incelediği çalışmasında, Cumhuriyet altını fiyatlarını etkileyen faktörler olarak Dow Jones endeksi, dolar kuru, dünya altın fiyatları, faiz oranı, IMKB 100 endeksi, petrol fiyatları ve TÜFE değişkenleri ele alınmıştır.
Çalışma sonucunda, IMKB 100 endeksi, Dow Jones endeksi, dolar kuru ve petrol fiyatının altın fiyatını etkilemediği, ancak dünya altın fiyatları, faiz oranı ve TÜFE'nin Cumhuriyet altını fiyatlarını etkilediği tespit edilmiştir.

Topçu'nun (2010), 1995:01-2009:09 döneminde altın fiyatlarını etkilediği düşünülen Dow Jones Sanayi Endeksi, dolar kuru, petrol fiyatı, Amerika enflasyon oranı gibi değişkenlere ilave olarak global para arzını da dahil ederek incelediği çalışmasında, Dow Jones Sanayi Endeksi ve dolar getirilerinin, altın getirilerini negatif yönde, global para arzını ise pozitif yönde etkilediği ortaya çıkmıştır. Ayrıca krizin altının getirisinde pozitif yönlü etkisi olduğu gözlenmiş ve petrol fiyatları ve enflasyon serisinin altın getirileri ile pozitif yönlü ilişkisi olmakla birlikte, ilişkinin gücünün istatistiksel olarak anlamlı olmadığı sonucuna varılmıştır.

Cılız (2010) çalışmasında, 2000-2008 yılları arasındaki döneme ilişkin altın arzı, madencilik, altın üretimi, altın talebi ve altın talebini etkileyen faktörler ile merkez bankalarının altın rezervlerinin konumu ve değerlendirilmesi konularında analizler yapılmıştır. Ayrıca, altının rezerv oranlarının ülkelerin makroekonomik verileriyle olan ilişkisini ortaya çıkartmak amacıyla kümeleme analizi ve panel veri analizi yöntemleri kullanıımıştır. Çalışma sonucunda, altın rezervleri ve altın talebi arasındaki ilişkiyi etkin kılan faktörün altın fiyatlarının değişimi olduğu, faiz, dolar ve borç stokunun altın rezerv oranları üzerinde etkili olduğu sonucu elde edilmiştir. Ayrıca, faiz oranlarındaki azalmayla beraber Avrupa ve $A B D$ 'de altın rezerv oranlarının arttığı görülmüştür.

Toraman, Başarır ve Bayramoğlu'nun (2011), 1992:01-2010:03 dönemini inceledikleri çalışmalarında, altın fiyatlarını etkileyen faktörler araştııımış ve altın fiyatları ile petrol fiyatları, ABD Dolar kuru, Dow Jones Sanayi Endeksi, ABD enflasyon oranı, $A B D$ reel faiz oranları arasında ilişki olup olmadığı MGARCH modelleri yardımıyla analiz edilmiştir. Çalışma sonucunda, sadece altın getirisi ile dolar getirisi arasında anlamlı bir doğrusal ilişkinin olduğu ortaya çıkarken ele alınan diğer değişkenlerin ise altın getirileri ile anlamlı bir doğrusal ilişkiye sahip olmadığı tespit edilmiştir.

Karataş ve Ürkmez'in (2013), 2007:01-2013:02 dönemini kapsayan çalışmalarında, küresel kriz sürecinde altın fiyatını belirleyen bazı kritik makroekonomik göstergeler ekonometrik olarak 
analiz edilmiştir. Çalışmada küresel finans krizi sürecinde altın fiyatlarını belirleyen unsurlar olarak Dow-Jones Endeksi, petrol fiyatları ve gümüş fiyatları ele alınmıştır. Elde edilen bulgular çerçevesinde, altın fiyatının beklendiği gibi kriz dönemlerinde arttığı ve uzun dönemde etkilendiği yorumu yapılmıştır.

Aksoy ve Topçu'nun (2013), 2003:01-2011:12 dönemini inceledikleri çalışmalarında, altın ile hisse senedi, devlet iç borçlanma senetleri (DiBS), tüketici fiyat endeksi (TÜFE) ve üretici fiyat endeksi (ÜFE) arasında kısa ve uzun dönemli bir ilişkinin olup olmadığı analiz edilmiştir. Sonuç olarak, altının hisse senetlerine karşı koruma amaçlı kullanılabileceği, enflasyona karşı değerini koruduğundan, güvenli bir yatırım aracı olduğu sonucuna varılmıştır. Ayrıca altın getirisi ile hisse senedi getirileri arasında negatif, ÜFE temelli hesaplanmış enflasyon ile pozitif bir ilişki olduğu ortaya çıkmıştır.

Yildız Contuk vd. (2013), 2009:01-2012:12 dönemini ele aldıkları çalışmalarında, IMKB 100 endeksi üzerinde altın fiyatlarındaki dalgalanmaların etkisini GARCH ve MGARCH modelleri kullanarak incelemişlerdir.

Elmas ve Polat (2013), 1 Ocak 1973-16 Haziran 2013 dönemini inceledikleri çalışmalarında, gümüş fiyatları ile Dow Jones Endeksi'nin altın fiyatlarına etkisini tespit etmek amacıyla eşbütünleşme ve nedensellik analizleri yapmışlardır. Ayrıca, seriler arasında uzun dönemli bir ilişki olup olmadığı araştırılmış ve uzun dönemli bir ilişkinin varlığı tespit edilmiştir. Bununla birlikte, altın fiyatları ile gümüş fiyatları arasında çift yönlü bir nedensellik ilişkisi bulunmuş fakat altın fiyatları ile Dow Jones Endeksi arasında bir nedensellik ilişkisine rastlanmamıştır.

Elmas ve Polat (2014), 1988:01-2013:03 dönemini kapsayan çalışmalarında, altın fiyatlarını etkileyen talep yönlü faktörleri araştırmışlardır. Altın fiyatını etkilediği düşünülen faktörlerden; döviz kuru, Dow Jones Endeksi, faiz oranı, enflasyon oranı, gümüş fiyatı ve petrol fiyatı faktörleri üzerine zaman serileri ile bir analiz yapılmıştır. Elde edilen sonuçlara göre, altın fiyatlarını; petrol fiyatları, gümüş fiyatları ve enflasyon oranının pozitif yönde, döviz kuru, Dow Jones Endeksi ve faiz oranının ise negatif yönde etkilediği tespit edilmiştir.

Türkiye'de altın piyasası ve altın fiyatlarını etkileyen faktörlerin ekonometrik bir uygulama ile araştırıldığı çalışmaların sınırlı sayıda olduğu görülmüştür. $\mathrm{Bu}$ çalışmalarda da genellikle çoklu regresyon modeli, nedensellik ve eşbütünleşme analizinden yararlanılmıştır. VAR modeli ile kapsamlı istatistiksel bir analizin yapıldığı bu çalışma diğer çalışmalardan önemli derecede ayrılmaktadır.

\section{VERI SETI VE YÖNTEM}

$\mathrm{Bu}$ çalışmada, İstanbul Altın Borsası (IAB) tarafından belirlenen altın fiyatlarının döviz kuru, faiz oranı, TÜFE, BIST 100 endeksi, ons fiyatları, petrol fiyatları değişkenlerinden ne derece etkilendiği ve söz konusu değişkenlerdeki beklenmeyen değişimlere ne derece tepki verdiği analiz edilmiştir. Bu amaçla, Ocak 2005- Nisan 2015 dönemine ait aylık veriler ele alınmıştır. Bu dönemin ele alınmasının nedenlerinden biri, 2005 yılına kadar tüm ülkelerce üretilen altın miktarının sürekli artış eğilimi göstermekte iken bu yılda düşmüş olmasıdır. Bir diğer neden ise, son 10 yıla ilişkin güncel verilerle altın fiyatlarını etkileyen faktörlerin incelenmek istenmesi ve çalışmaya Mayıs 2015 tarihinde başlanmasıdır.

Petrol fiyatları hariç tüm değişkenlere ait veriler T.C. Merkez Bankası Elektronik Veri Dağıtım Sisteminden (http://evds.tcmb.gov.tr) elde edilmiştir. Petrol fiyatı verileri ise ham Petrol varil fiyatları olup T.C. Enerji Piyasası Düzenleme Kurumu (http://epdk. org.tr) raporlarından derlenmiştir.

\subsection{Araştırmada Kullanılan Veriler}

Yapılan literatür araştırması sonucunda Türkiye'deki altın fiyatlarının açıklanmasında kullanılacak bağımsız değişkenler kur değerleri, faiz oranları, uluslararası altın fiyatları, enflasyon oranları, borsa endeks değerleri olarak belirlenmiştir. IAB tarafından belirlenen altın fiyatlarını etkileyen faktörlere ilişkin olarak uygulamada kullanılan değişkenlerin açıklamaları aşağıda verilmiştir:

IAB altın fiyatları: İstanbul Altın Borsası (IAB)'nda oluşan 1 ons altının TL cinsinden aylık ağırlıklı ortalama fiyatıdır.

Döviz Kuru: USD-Dolar alış fiyatının aylık ortalama değerleridir.

Ons(TL): Londra altın piyasasında belirlenen altın fiyatlarının göstergesi olarak 1 ons altının TL cinsinden fiyatıdır.

Faiz Oranı: Faiz göstergesi olarak, TCMB tarafından yayınlanan 1 aya kadar vadeli ağırlıklı ortalama vadeli mevduat faiz oranları kullanılmıştır. 
Petrol Fiyatları: Ham petrol varil fiyatının TL cinsinden değeridir.

TÜFE: Enflasyon göstergesi olup Tüketici Fiyat Endeksi'ni temsil etmektedir (2003=100).

BiST 100: BIST 100 endeksine ilişkin kapanış verilerinin aylık endeks değerleri kullanılmıştır.

\subsection{Araştırma Yöntemi}

Değişkenler arasında ekonometrik olarak anlamlı ilişkiler elde edilebilmesi için analizi yapılan serilerin durağan seriler olması gerekmektedir. Bunun için farklı yöntemler geliştirilmiş olmakla birlikte Geliştirilmiş Dickey Fuller (ADF) ve Phillips Peron testleri ile serilerin durağan olup olmadıkları belirlenebilmektedir (Tarı, 2012). ADF testi aşağıdaki eşitlikte verilmiştir:

$$
\Delta Y_{t}=\mu+\beta t+\delta Y_{t-1}+\sum_{j=1}^{k} \alpha_{1} \Delta Y_{t-j}+\varepsilon_{t}
$$

Burada, $\Delta Y_{t}$ durağanlığı test edilen zaman serisini, $\mu v e \beta t$, incelenen zaman serisinde sistematik bir trendin olup olmadığını belirleyen katsayıları ve $\varepsilon_{t}$ rassal hata terimini ifade etmektedir.

ADF testi ile, $H_{0}: \delta=0$ (Birim kök vardır) hipotezi test edilir, $H_{0}$ hipotezinin reddedilmesi seride birim kök olmadığı başka bir ifadeyle serinin durağan olduğu anlamına gelmektedir. ADF testini uygularken dikkate edilmesi gereken en önemli nokta uygun gecikme sayısının belirlenmesidir. Uygun gecikme belirlenirken Akaike bilgi kriteri (AIC) veya Schwarz bilgi kriterinden (SIC) faydalanılabilir. En küçük AIC (veya SIC) değerini veren model en uygun model olarak kullanılmaktadır (Fuller, 1996). PhillipsPerron (1988) testi yaygın olarak kullanılan ve yapısal kırımayı dikkate almayan bir diğer testtir.

İktisadi verilere ait seriler durağan olmasalar bile bu serilerin durağan bir doğrusal kombinasyonun varlığı bu seriler arasında eşbütünleşme olduğunu gösterir. Böylece uzun dönem bilgi kaybı engellenmiş olur. Uzun dönemde söz konusu değişkenler arasında anlamlı bir ilişkinin olup olmadığını, kısaca eşbütünleşmenin varlığını tespit etmek için Engle\&Granger (1987) ve Johansen Eşbütünleşme $(1988,1995)$ testleri kullanılmaktadır. Eğer seriler eşbütünleşik ise, kısa ve uzun dönemde veriler arasındaki nedensellik ilişkisi ve ilişkinin yönü, en çok tercih edilen yöntem olan Granger Nedensellik testi yardımıyla araştırılmaktadır. Granger nedensellik ilişkisi araştırılırken aşağıdaki eşitlikler uygulanır:

$$
\begin{aligned}
& Y_{t}=\sum_{i=1}^{n} \alpha_{i} Y_{t-i}+\sum_{i=1}^{n} \beta_{i} X_{t-i}+u_{1 t} \\
& X_{t}=\sum_{i=1}^{n} \alpha_{i} X_{t-i}+\sum_{i=1}^{n} \beta_{i} Y_{t-i}+u_{2 t}
\end{aligned}
$$

Burada, $u_{1 t}$ ve $u_{2 t}$ hata terimlerinin ilişkisiz oldukları varsayılmaktadır (Kutlar, 2007).

Ekonometrik araştırmalarda ilişkiler arasındaki etkileşimin karmaşık ve çok yönlü olması eşanlı denklem sistemlerinin kullanılmasını gerektirmektedir. Eşanlı denklem sistemlerinin çözümüne yönelik olarak geliştirilen yöntemlerden biri de Vektör Otoregresif Modelleri (VAR)'dir. VAR modeli p değişken için aşağıdaki eşitlikle gösterilebilir:

$$
y_{t}=A_{1} y_{t-1}+\ldots+A_{p} y_{t-p}+B x_{t}+\varepsilon_{t}
$$

Burada, $y_{t} \mathrm{px} 1$ boyutundaki değişken vektörü, $x_{t}(\mathrm{dx} 1)$ boyutlu determinist değişkenler, $A_{i}$ (pxp) boyutlu parametre matrisleri ve hata terimleri vektörüdür (Johansen,1995).

VAR modelleri, yapısal modele herhangi bir kısıtlama getirmediğinden zaman serileri için tercih edilmekte olup değişkenlerin içsel-dışsal ayrımını gerektirmemektedir. Ayrıca VAR modellerinde bağımlı değişkenlerin gecikmeli değerleri yer aldığından geleceğe yönelik güçlü tahminlerin yapılması da mümkündür. VAR modeli ile hesaplanan katsayıların yorumlanması oldukça karmaşık ve zor olduğu için, genellikle etki-tepki analizi ve varyans ayrıştırması yöntemleri uygulanmaktadır (Gacener, 2005). Etkitepki analizi, değişkenlerden birine bir birimlik şok uygulandığında diğer değişken veya değişkenlerin bu değişime gösterdikleri tepkiyi vermektedir. Varyans ayrıştırması ise, incelenen değişkenlerin her birinin varyansında meydana gelen değişmenin $\%$ kaçının kendi gecikmeleriyle, \% kaçının ise diğer değişkenlerce açıklandığını araştııır (Tarı, 2012).

\section{UYGULAMA}

Uygulama aşamasında öncelikle, değişkenlerin grafikleri incelenmiş ve hem varyans dengesini sağlamak hem de uç değerlerin etkisinden kurtulmak 
amacıyla tüm değişkenlerin doğal logaritmaları alınmıştır. Analizde serilerin orijinal değerleri yerine doğal logaritmik dönüştürülmüş halleri değişken olarak kullanılmıştır ve bu değişkenlere ait tanımlayıcı istatistikler ile korelasyon matrisi elde edilmiştir. Daha sonra gözlem değerlerinin logaritmik değerlerinin birinci fark serilerine ilişkin zaman serisi grafikleri çizilmiştir. Serilerin durağanlıklarının araştıııması için hem ADF hem de Phillips-Perron (PP) birim kök testleri yapıldıktan sonra incelenen değişkenlere ilişkin VAR modeli elde edilmiştir. Bunun için önce en uygun gecikme uzunluğu belirlenmiştir. Bulunan gecikme uzunluğuna uygun olarak oluşturulmuş VAR modeli için değişen varyans ve otokorelasyon varsayımları incelenmiştir. Son olarak da Etki-tepki analizleri ve Varyans ayrıştırması yapılmıştır.

Analize alınan tüm değişkenlere ilişkin tanımlayıcı istatistikler Tablo 1'de verilmiştir. Tabloda da görüldüğü gibi standart sapması en büyük yani değişkenliği en yüksek olan değişkenin $I A B$ ve Ons değişkenleri olduğu görülmektedir. Ayrıca değişkenlere ilişkin Tablo 2'de verilen korelasyon matrisine göre, özellikle IAB altın fiyatı ele alındığında, IAB ile Ons arasında pozitif kuvvetli bir ilişki olup BIST 100 endeksi ile negatif bir ilişki vardır. Bu sonuç Yıldız (2014)'ın çalışmasıyla paralel bir sonuç ortaya koymuştur. Ayrıca faiz, TÜFE ve petrol ile IAB arasında da pozitif zayıf bir ilişki olurken döviz kuru ile orta düzeyde pozitif ilişki mevcuttur.

Tablo 1: Değişkenlere Ait Tanımlayıcı İstatistikler

\begin{tabular}{|l|c|c|c|c|c|c|c|}
\hline & LN_IABTL & LN_DOVKUR & LN_ONSTL & LN_FAIZ & LN_PETROLTL & LN_TUFE & LN_BIST \\
\hline Ortalama & 10.8400 & 0.4672 & 3.9328 & 2.3778 & 4.7841 & 5.1492 & 10.8370 \\
\hline Medyan & 10.8981 & 0.4318 & 3.9989 & 2.2154 & 4.7715 & 5.1727 & 10.9007 \\
\hline Maksimum & 11.5417 & 0.9746 & 4.6251 & 2.9481 & 5.4067 & 5.5583 & 11.4086 \\
\hline Minimum & 9.7924 & 0.1570 & 2.8827 & 1.6658 & 3.9455 & 4.7405 & 10.0905 \\
\hline St. Sapma & 0.5627 & 0.1923 & 0.5589 & 0.3931 & 0.3810 & 0.2356 & 0.3574 \\
\hline Çarpıklık & -0.3323 & 0.5193 & -0.3360 & 0.1398 & -0.1491 & -0.0728 & -0.4301 \\
\hline Basıkıık & 1.7305 & 2.5419 & 1.7253 & 1.4158 & 1.9776 & 1.8774 & 2.2130 \\
\hline Jarque Bera & 10.6087 & 6.6573 & 10.7285 & 13.3707 & 5.8596 & 6.6208 & 7.0234 \\
\hline & 0.0050 & 0.0358 & 0.0047 & 0.0012 & 0.0534 & 0.0365 & 0.0298 \\
\hline Gözlemsayısı & 124 & 124 & 124 & 124 & 124 & 124 & 124 \\
\hline
\end{tabular}

Tablo 2: Değişkenler Arasındaki Korelasyon Matrisi

\begin{tabular}{lccccccc}
\hline & FLNIAB & FLNDOVKUR & FLNONS & FLNFAIZ & FLNPETROL & FLNTUFE & FLNBIST \\
\hline FLNIAB & 1.000000 & & & & & & \\
FLNDOVKUR & 0.487821 & 1.000000 & & & & & \\
FLNONS & 0.897198 & 0.496077 & 1.000000 & & & & \\
FLNFAIZ & 0.027743 & 0.261096 & -0.026845 & 1.000000 & & & \\
FLNPETROL & 0.063373 & -0.023039 & 0.120567 & -0.009747 & 1.000000 & & \\
FLNTUFE & 0.112593 & 0.148435 & 0.176102 & 0.020725 & 0.095299 & 1.000000 & \\
FLNBIST & -0.404526 & -0.723558 & -0.423893 & -0.371085 & 0.004466 & -0.120273 & 1.000000 \\
\hline
\end{tabular}

Şekil 1'de ise değişkenlerin logaritmik değerlerine ilişkin serilerin birinci farklarında durağan hale geldiği gözlemlenmektedir. Bu grafik incelendiğinde, serilerin daha istikrarlı bir konuma geçtikleri görülmektedir. Çalışmada kullanılan serilerin durağan olup olmadığını belirlemek için Genişletilmiş Dickey Fuller (ADF) ve Phillips Peron Testi uygulanmıştır. Test istatistikleri hem sabit terim hem de doğrusal trend 
için hesaplanmıştır. Tablo 3, değişkenlerin logaritmik ve logaritmik değerlerin birinci farklarına ait ADF ve PP birim kök test sonuçlarını göstermektedir. Serinin birim köke sahip olması, durağan olmadığını göstermektedir. IAB altın fiyatı, döviz kuru, ons, faiz oranı, petrol fiyatları, TÜFE ve BIST 100 endeksi değişkenlerinin logaritmik düzeylerinde birim köke sahip olduğu yani durağan bir yapıya sahip olmadığı, belli bir ortalama etrafında dağılım göstermediği ADF ve PP ile test edilmiştir. Uygulanan testler sonucunda tüm değişkenlerin logaritmik düzeylerinde durağan olmayıp logaritmik değerlerin birinci farklarında durağan olduğu I(1) görülmektedir.

Tablo 3: ADF ve PP Birim Kök Testi

\begin{tabular}{|c|c|c|c|c|}
\hline & \multicolumn{2}{|c|}{ ADF Testi } & \multicolumn{2}{|c|}{ Phillips-Perron Testi } \\
\hline & $\begin{array}{c}\text { Sabit terimli } \\
\text { model* }^{*}\end{array}$ & $\begin{array}{l}\text { Sabit terimli ve } \\
\text { trendli model** }\end{array}$ & Sabit terimli model & $\begin{array}{c}\text { Sabit terimli ve } \\
\text { trendli model }\end{array}$ \\
\hline LİAB & $\begin{array}{l}-1.3571 \\
(0.6011)\end{array}$ & $\begin{array}{l}-1.5014 \\
(0.8241)\end{array}$ & $\begin{array}{l}-1.3431 \\
(0.6078)\end{array}$ & $\begin{array}{l}-1.6088 \\
(0.7841)\end{array}$ \\
\hline LDÖVKUR & $\begin{array}{c}0.3704 \\
(0.9809)\end{array}$ & $\begin{array}{l}-2.2557 \\
(0.4544)\end{array}$ & $\begin{array}{c}0.3759 \\
(0.9812)\end{array}$ & $\begin{array}{l}-1.5040 \\
(0.8232)\end{array}$ \\
\hline LONS & $\begin{array}{l}-1.5209 \\
(0.5198)\end{array}$ & $\begin{array}{l}-1.9503 \\
(0.6220)\end{array}$ & $\begin{array}{l}-1.3967 \\
(0.5820)\end{array}$ & $\begin{array}{l}-1.3832 \\
(0.8613)\end{array}$ \\
\hline LFAiZ & $\begin{array}{l}-1.4512 \\
(0.5549)\end{array}$ & $\begin{array}{l}-1.8305 \\
(0.6839)\end{array}$ & $\begin{array}{l}-1.4789 \\
(0.5411)\end{array}$ & $\begin{array}{l}-1.2696 \\
(0.8905)\end{array}$ \\
\hline LPETROL & $\begin{array}{l}-2.4313 \\
(0.1354)\end{array}$ & $\begin{array}{l}-3.7554 \\
(0.0224)\end{array}$ & $\begin{array}{l}-2.2812 \\
(0.1797)\end{array}$ & $\begin{array}{l}-3.0450 \\
(0.1245)\end{array}$ \\
\hline LTÜFE & $\begin{array}{l}-0.4831 \\
(0.8895)\end{array}$ & $\begin{array}{l}-4.1322 \\
(0.0074)\end{array}$ & $\begin{array}{l}-0.0653 \\
(0.9498)\end{array}$ & $\begin{array}{l}-2.9347 \\
(0.1554)\end{array}$ \\
\hline LBIST & $\begin{array}{l}-1.5810 \\
(0.4892)\end{array}$ & $\begin{array}{l}-2.6911 \\
(0.2422)\end{array}$ & $\begin{array}{l}-1.6623 \\
(0.4478)\end{array}$ & $\begin{array}{l}-2.6758 \\
(0.2485)\end{array}$ \\
\hline$\Delta(\mathrm{LI} A \mathrm{~B})$ & $\begin{array}{l}-9.9134 \\
(0.0000)\end{array}$ & $\begin{array}{l}-9.9667 \\
(0.0000)\end{array}$ & $\begin{array}{l}-9.9185 \\
(0.0000)\end{array}$ & $\begin{array}{l}-9.9416 \\
(0.0000)\end{array}$ \\
\hline$\Delta$ (LDÖVKUR) & $\begin{array}{l}-8.0228 \\
(0.0000)\end{array}$ & $\begin{array}{l}-8.1541 \\
(0.0000)\end{array}$ & $\begin{array}{l}-7.9427 \\
(0.0000)\end{array}$ & $\begin{array}{l}-7.9672 \\
(0.0000)\end{array}$ \\
\hline$\Delta($ LONS $)$ & $\begin{array}{l}-8.7153 \\
(0.0000)\end{array}$ & $\begin{array}{l}-8.7698 \\
(0.0000)\end{array}$ & $\begin{array}{l}-8.6417 \\
(0.0000)\end{array}$ & $\begin{array}{l}-8.6636 \\
(0.0000)\end{array}$ \\
\hline$\Delta($ LFAiZ) & $\begin{array}{l}-6.4506 \\
(0.0000)\end{array}$ & $\begin{array}{l}-6.4503 \\
(0.0000)\end{array}$ & $\begin{array}{l}-6.3356 \\
(0.0000)\end{array}$ & $\begin{array}{l}-6.3195 \\
(0.0000)\end{array}$ \\
\hline$\Delta$ (LPETROL) & $\begin{array}{l}-7.4830 \\
(0.0000)\end{array}$ & $\begin{array}{l}-7.5036 \\
(0.0000)\end{array}$ & $\begin{array}{l}-7.4830 \\
(0.0000)\end{array}$ & $\begin{array}{l}-7.5277 \\
(0.0000)\end{array}$ \\
\hline$\Delta$ (LTÜFE) & $\begin{array}{l}-7.8898 \\
(0.0000)\end{array}$ & $\begin{array}{l}-7.8625 \\
(0.0000)\end{array}$ & $\begin{array}{r}-15.7804 \\
(0.0000)\end{array}$ & $\begin{array}{r}-16.6812 \\
(0.0000)\end{array}$ \\
\hline$\Delta$ (LBIST) & $\begin{array}{l}-8.5038 \\
(0.0000)\end{array}$ & $\begin{array}{l}-8.4704 \\
(0.0000)\end{array}$ & $\begin{array}{l}-8.5008 \\
(0.0000)\end{array}$ & $\begin{array}{l}-8.4664 \\
(0.0000)\end{array}$ \\
\hline Kritik değer \%1 & -3.4842 & -4.0344 & -3.4847 & -4.0350 \\
\hline Kritik değer \%5 & -2.8851 & -3.4468 & -2.8853 & -3.4471 \\
\hline Kritik değer \%10 & -2.5794 & -3.1484 & -2.5795 & -3.1486 \\
\hline
\end{tabular}

Not: $\triangle$ ifadesi birinci farkları, L ise logaritmik değerlerini göstermektedir. ADF ve PP için kritik değerler MacKinnon (1996) tarafından elde edilmiştir. Parantez içindeki değerler MacKinnon (1996) tek yönlü p olasılık değerleridir. ${ }^{*} p<0.01$. 

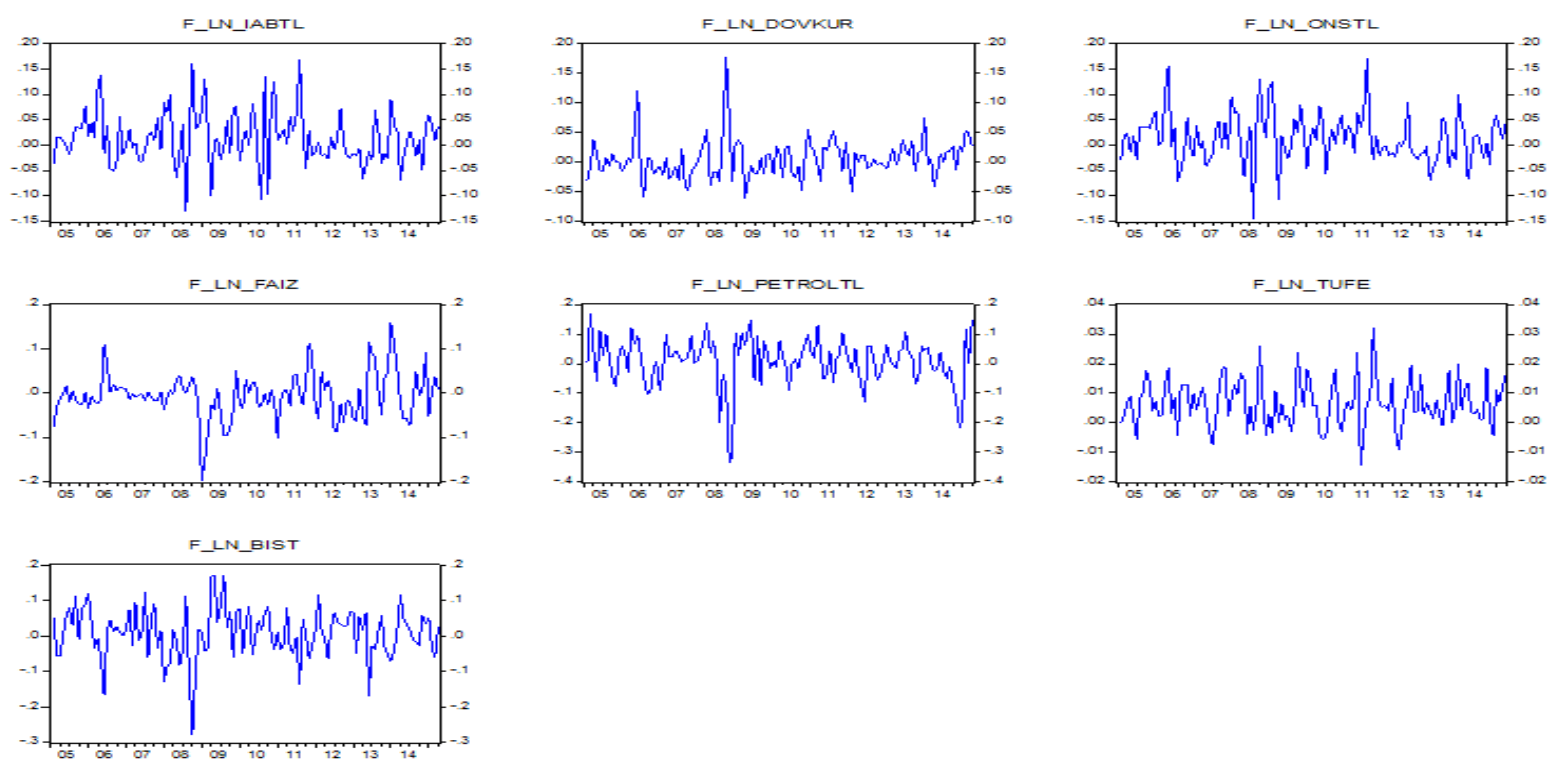

Şekil 1: Değişkenlerin Logaritmik Değerlerine Ilişkin Serilerin Birinci Farklarının Grafiği

Serilerin durağanlık testinin ardından, VAR modeli ile analize başlamadan önce en uygun gecikme uzunluğunun belirlenmesi aşamasına geçilmiştir (Tablo 4). Uygun gecikme uzunluğunun hatalı belirlenmesi durumunda, etki-tepki analizleri ve varyans ayrıştırması aşamalarında tutarsız sonuçlar ortaya çıkabilmektedir. Gecikme uzunluğunun olması gerekenden büyük olması durumunda tahminlerin ortalama hata karelerini yükseltmesi ve parametre tahminleri varyansının yüksek çıkması ihtimali söz konusudur. Gecikme uzunluğu olması gerekenden küçük hesaplandığında ise otokorelasyonlu hata terimleri ortaya çıkmaktadır (Özçiçek ve McMillin, 1999). Buna göre, Tablo 4'te görüldüğü gibi, LR, FPE ve AIC kriterlerine göre en uygun gecikme uzunluğunun 2 olduğu görülmektedir.

Değişkenler arasındaki uzun dönem ilişkilerini istatistiksel olarak analiz edebilmek için serilerin aynı dereceden bütünleşik olmaları gerekir. Bu çalışmada ele alınan değişkenlerin tümünün birinci farklarında birim kök içermemesinden dolayı bu serilerin aynı dereceden bütünleşik seriler olduğu ve bu seriler arasında eşbütünleşme ilişkisinin araştırılabileceği belirlenmiştir. Uzun dönemde söz konusu değişkenler arasında anlamlı bir ilişkinin olup olmadığını tespit etmek için Johansen Eşbütünleşme testi kullanılmıştır. Bu teste ait sonuçlar Tablo 5'te sunulmuştur. Eşbütünleşme analizi sonuçları incelendiğinde, \%5 anlamlılık düzeyinde, seriler arasında İz test istatistiği için 'eşbütünleşme yoktur' hipotezi reddedilirken Max-özdeğer istatistiği için reddedilememektedir. Ayrıca \%1 anlamlılık düzeyinde ise, her iki test istatistiği için de 'eşbütünleşme yoktur' hipotezi reddedilemediğinden, İAB altın fiyatı, döviz kuru, ons, faiz oranı, petrol fiyatları, TÜFE ve BiST 100 endeksi değişkenleri arasında uzun dönemli bir ilişkinin bulunmadığı söylenebilir.

Çalışmada ele alınan değişkenler için oluşturulan VAR modelinin durağan olup olmadığını incelemek için AR karakteristik polinomunun ters köklerine bakılır. Şekil 2'de, AR karakteristik polinomunun ters köklerinin birim çember içerisindeki dağılımı yer almaktadır. Buna göre, modelin tüm ters kökleri birim çemberin içinde olduğundan, oluşturulan VAR modelinin durağan yani istikrarlı bir yapıda olduğu söylenebilir.

Değişkenler arasındaki nedenselliğin yönünün belirlenmesi amacıyla, VAR modeline dayalı Granger nedensellik testi sonuçları elde edilmiştir (Tablo 6). Elde edilen bulgulara göre, petrol fiyatı döviz kurunun Granger nedenidir ( $p<0.10$ ). Ayrıca, Ons fiyatı IAB altın fiyatının Granger nedeni olurken petrol fiyatı da Ons fiyatının Granger nedenidir ( $p<0.05$ ).

Belirlenen gecikme uzunluğuna göre oluşturulan VAR(2) modeline ilişkin tahmin sonuçları Tablo 7'de gösterilmiştir. 
Tablo 4: Ilgili Kriterlere Göre Optimum Gecikme Uzunluğu

\begin{tabular}{|c|c|c|c|c|c|c|}
\hline Lag & LogL & LR & FPE & AIC & SC & HQ \\
\hline & & & & & & \\
\hline 0 & 589.7026 & NA & $1.02 \mathrm{e} 13-$ & -10.04660 & -9.880432 & -9.979144 \\
\hline 1 & 1696.979 & 2061.825 & $1.22 \mathrm{e} 21-$ & -28.29275 & $26.9634-^{*}$ & $27.7531-^{*}$ \\
\hline 2 & 1765.744 & $119.7463^{*}$ & $8.74 \mathrm{e} 22-^{*}$ & $28.6335-^{*}$ & -26.14105 & -27.62172 \\
\hline 3 & 1802.086 & 58.89769 & $1.11 \mathrm{e} 21-$ & -28.41527 & -24.75964 & -26.93129 \\
\hline 4 & 1833.577 & 47.23639 & $1.57 \mathrm{e} 21-$ & -28.11339 & -23.29461 & -26.15724 \\
\hline 5 & 1870.344 & 50.71410 & $2.09 \mathrm{e} 21-$ & -27.90249 & -21.92055 & -25.47416 \\
\hline 6 & 1911.156 & 51.36662 & $2.68 \mathrm{e} 21-$ & -27.76131 & -20.61622 & -24.86081 \\
\hline 7 & 1952.492 & 47.03800 & $3.60 \mathrm{e} 21-$ & -27.62918 & -19.32093 & -24.25651 \\
\hline 8 & 1997.935 & 46.22566 & $4.82 \mathrm{e} 21-$ & -27.56784 & -18.09644 & -23.72299 \\
\hline
\end{tabular}

*ilgili kriter tarafından belirlenen optimum uzunluktur.

Tablo 5: Johansen Eşbütünleşme Testi

\begin{tabular}{|c|c|c|c|c|c|c|c|}
\hline $\begin{array}{c}\mathrm{H}_{0} \\
\text { Hipotezi }\end{array}$ & Özdeğer & $\begin{array}{c}\text { İz } \\
\text { İstatistiği }\end{array}$ & $\begin{array}{c}\% 5 \\
\text { Kritik } \\
\text { değer }\end{array}$ & Olasılık** & $\begin{array}{c}\text { Max- Özdeğer } \\
\text { Istatistiği }\end{array}$ & $\begin{array}{c}\% 5 \\
\text { Kritik } \\
\text { değer }\end{array}$ & Olasılık** \\
\hline & 0.30915 & 135.4392 & 125.6154 & $0.0109^{*}$ & 44.7495 & 46.2314 & 0.0715 \\
\hline & 0.2538 & 90.6897 & 95.7537 & 0.1060 & 35.4205 & 40.0776 & 0.1526 \\
\hline & 0.1526 & 55.2692 & 69.8189 & 0.4078 & 20.0418 & 33.8769 & 0.7538 \\
\hline & 0.1332 & 35.2274 & 47.8561 & 0.4360 & 17.2977 & 27.5843 & 0.5545 \\
\hline & 0.0941 & 17.9297 & 29.7971 & 0.5713 & 11.9581 & 21.1316 & 0.5518 \\
\hline & 0.0482 & 5.9716 & 15.4947 & 0.6989 & 5.9716 & 14.2646 & 0.6169 \\
\hline & $3.51 \mathrm{E} 08-$ & $4.25 \mathrm{E} 06-$ & 3.8415 & 0.9995 & $4.25 \mathrm{E} 06-$ & 3.8415 & 0.9995 \\
\hline
\end{tabular}

*\%5 anlamlılık düzeyinde boş hipotezin reddedildiğini gösterir.

**MacKinnon-Haug-Michelis (1999)'e göre olasılık değerlerini gösterir.

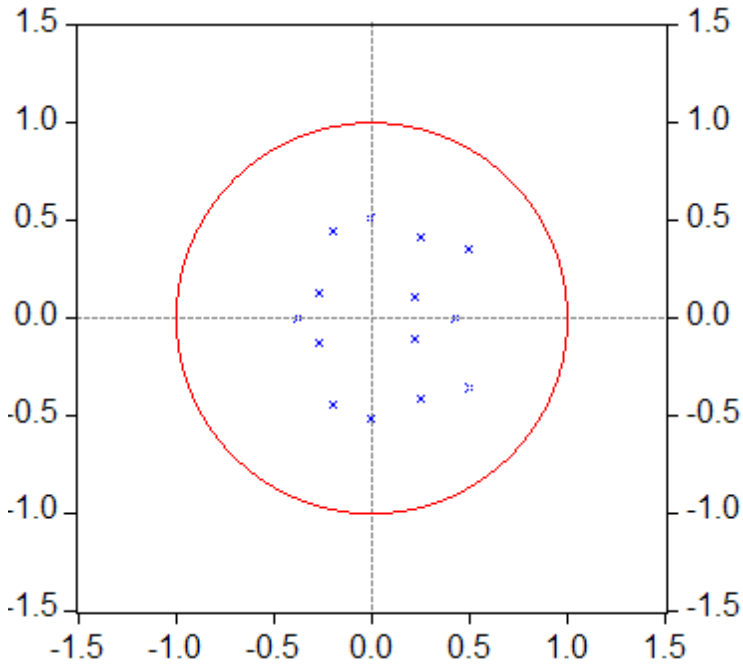

Şekil 2: AR Karakteristik Polinomunun Ters Kökleri
VAR modeli parametrelerinin doğrudan yorumlanması pek anlamlı olmayacağından etkitepki ve varyans ayrıştırma analizleri ile yorumlamaları yapılmıştır. Ayrıca VAR(2) modeline ilişkin değişen varyans ve otokorelasyon varsayımları incelendiğinde, $\operatorname{VAR}(2)$ modeli için tüm gecikme düzeylerinde otokorelasyonun varlığı tespit edilememiştir. Bununla birlikte, söz konusu modelde değişen varyans sorununu tespit amacıyla uygulanan White Değişen Varyans Testi sonucunda 0.05 anlamlılık düzeyinde modelde değişen varyans sorununun olmadığı görülmektedir (Tablo 8). 
Tablo 6: Granger Nedensellik Testi

\begin{tabular}{|l|c|c|c|}
\hline Değişkenler & Ki-kare & Serb.Der. & p-olasılığı \\
\hline $\mathrm{H}_{0}:$ Ons, IAB altın fiyatının granger nedeni değildir. & 21.20906 & 2 & $0.0000^{* *}$ \\
\hline $\mathrm{H}_{0}:$ Petrol, döviz kurunun granger nedeni değildir. & 5.667230 & 2 & $0.0588^{*}$ \\
\hline $\mathrm{H}_{0}:$ Petrol, Ons'un granger nedeni değildir. & 6.452739 & 2 & $0.0397^{* *}$ \\
\hline $\mathrm{H}_{0}:$ TÜFE, faiz oranının granger nedeni değildir. & 12.06613 & 2 & $0.0024^{* *}$ \\
\hline $\mathrm{H}_{0}:$ :Döviz kuru, petrolün granger nedeni değildir. & 6.264989 & 2 & $0.0436^{* *}$ \\
\hline
\end{tabular}

Tablodaki değerler, sadece anlamlı çıkan nedensellik sonuçlarına ilişkindir. * $p<0.10$, ** $p<0.05$

Tablo 7: Var(2) Modeline Illişkin Analiz Sonuçları

\begin{tabular}{|c|c|c|c|c|c|c|c|}
\hline & FLNIAB & FLNDOVKUR & FLNONS & FLNFAIZ & FLNPETROL & FLNTUFE & FLNBIST \\
\hline \multirow[t]{2}{*}{ FLNIAB(-1) } & -0.820523 & 0.073928 & -0.202729 & -0.422789 & 0.509881 & 0.021923 & 0.049440 \\
\hline & {$[-3.48417]$} & [ 0.48996$]$ & {$[-0.88047]$} & {$[-2.09275]$} & [ 1.39064] & [ 0.59065$]$ & [ 0.14642$]$ \\
\hline \multirow[t]{2}{*}{ FLNIAB(-2) } & -0.256245 & 0.058558 & -0.122079 & -0.172840 & 0.443193 & -0.010210 & -0.037966 \\
\hline & {$[-1.07842]$} & [ 0.38464$]$ & {$[-0.52549]$} & {$[-0.84793]$} & [ 1.19801] & {$[-0.27264]$} & {$[-0.11144]$} \\
\hline \multirow[t]{2}{*}{ FLNDOVKUR(-1) } & 0.073214 & 0.218039 & 0.039813 & 0.117941 & -0.791984 & 0.009256 & -0.262387 \\
\hline & {$[0.32658]$} & [ 1.51803$]$ & [0.18164] & [0.61327] & [-2.26912] & [0.26195] & {$[-0.81633]$} \\
\hline \multirow[t]{2}{*}{ FLNDOVKUR(-2) } & -0.080598 & -0.137611 & 0.013939 & -0.010540 & 0.408900 & -0.044136 & 0.233359 \\
\hline & {$[-0.37991]$} & {$[-1.01241]$} & [0.06720] & {$[-0.05792]$} & [ 1.23799] & [-1.32001] & [0.76720] \\
\hline \multirow[t]{2}{*}{ FLNONSTL(-1) } & 1.087800 & 0.015382 & 0.412907 & 0.222076 & -0.326838 & -0.024361 & 0.008988 \\
\hline & [ 4.47351] & [0.09873] & [ 1.73676] & [ 1.06460$]$ & {$[-0.86332]$} & {$[-0.63565]$} & [ 0.02578$]$ \\
\hline \multirow[t]{2}{*}{ FLNONS(-2) } & 0.175245 & -0.120763 & 0.075973 & 0.130853 & -0.404885 & 0.051090 & 0.171889 \\
\hline & [0.66169] & {$[-0.71169]$} & [0.29340] & [0.57595] & [-0.98193] & [ 1.22395] & [ 0.45267$]$ \\
\hline \multirow[t]{2}{*}{ FLNFAIZ(-1) } & -0.043747 & -0.079057 & -0.028629 & 0.435770 & 0.080438 & 0.039279 & 0.071981 \\
\hline & {$[-0.35083]$} & {$[-0.98952]$} & {$[-0.23482]$} & [ 4.07367] & [0.41433] & [ 1.99859] & 261] \\
\hline \multirow[t]{2}{*}{ FLNFAIZ(-2) } & 0.060650 & 0.047222 & 0.047710 & -0.081593 & -0.342689 & -0.022192 & -0.055139 \\
\hline & {$[0.53132]$} & [ 0.64568$]$ & [0.42748] & {$[-0.83322]$} & [-1.92826] & {$[-1.23349]$} & 690 \\
\hline \multirow[t]{2}{*}{ FLNPETROL(-1) } & -0.009137 & & & 0.078297 & & .008028 & -0.069353 \\
\hline & {$[-0.14505]$} & {$[-0.13023]$} & [-0.11818] & [ 1.44887] & [ 3.45956] & [0.80857] & {$[-0.76787]$} \\
\hline \multirow[t]{2}{*}{ FLNPETROL(-2) } & -0.097875 & -0.086503 & -0.141343 & 0.036294 & -0.041690 & -0.012592 & 0.149691 \\
\hline & {$[-1.58703]$} & [-2.18921] & [-2.34411] & [0.68602] & {$[-0.43419]$} & {$[-1.29545]$} & [ 1.69290$]$ \\
\hline \multirow[t]{2}{*}{ FLNTUFE(-1) } & -0.837625 & -0.302305 & -0.670039 & 1.521042 & -0.244166 & 0.250203 & -1.008297 \\
\hline & [-1.38477] & {$[-0.78004]$} & {$[-1.13297]$} & [ 2.93126] & {$[-0.25927]$} & [ 2.62446] & {$[-1.16262]$} \\
\hline \multirow[t]{2}{*}{ FLNTUFE(-2) } & 0.602181 & 0.359102 & 0.022886 & 0.651467 & -0.161537 & -0.283737 & -0.171456 \\
\hline & [0.93393] & {$[0.86925]$} & [0.03630] & [ 1.17778$]$ & {$[-0.16092]$} & [-2.79204] & {$[-0.18546]$} \\
\hline \multirow[t]{2}{*}{ FLNBIST(-1) } & -0.030130 & -0.080295 & -0.037565 & -0.100063 & 0.002586 & 0.013176 & 0.206237 \\
\hline & {$[-0.30227]$} & {$[-1.25728]$} & {$[-0.38545]$} & {$[-1.17020]$} & [0.01666] & [ 0.83870$]$ & [ 1.44307$]$ \\
\hline \multirow[t]{2}{*}{ FLNBIST(-2) } & 0.040909 & 0.037578 & 0.084522 & 0.006898 & 0.138678 & -0.004519 & 0.071336 \\
\hline & {$[0.41146]$} & [ 0.58992] & [0.86950] & [0.08088] & [0.89590] & {$[-0.28838]$} & [ 0.50043$]$ \\
\hline \multirow[t]{2}{*}{ C } & 0.014072 & 0.005494 & 0.016661 & -0.014859 & 0.003850 & 0.006606 & 0.011942 \\
\hline & [ 1.94379$]$ & [ 1.18454$]$ & [ 2.35393] & {$[-2.39268]$} & {$[0.34163]$} & [ 5.78943] & [ 1.15057$]$ \\
\hline $\mathrm{R}^{2}$ & 0.246676 & 0.230981 & 0.158877 & 0.422203 & 0.241872 & 0.174681 & 0.130130 \\
\hline
\end{tabular}


Tablo 8: Otokorelasyon-LM Testi ve White Değişen Varyans Testi Sonuçları

\begin{tabular}{|c|c|c|}
\hline \multicolumn{3}{|c|}{ Otokorelasyon-LM Testi Sonuçları } \\
\hline Gecikme & LM İstatistiği & Olasılık değeri \\
\hline 1 & 50.12393 & 0.4286 \\
\hline 2 & 47.39276 & 0.5385 \\
\hline 3 & 45.25283 & 0.6258 \\
\hline 4 & 48.51256 & 0.4928 \\
\hline 5 & 50.77273 & 0.4036 \\
\hline 6 & 51.27755 & 0.3845 \\
\hline 7 & 49.36022 & 0.4587 \\
\hline 8 & 58.41374 & 0.1679 \\
\hline 9 & 53.57838 & 0.3030 \\
\hline 10 & 52.54245 & 0.3385 \\
\hline 11 & 51.20698 & 0.3871 \\
\hline 12 & 46.35140 & 0.5811 \\
\hline \multicolumn{3}{|c|}{ White Değişen Varyans Testi Sonuçları } \\
\hline Kikare & $\begin{array}{c}\text { Serbestlik } \\
\text { derecesi }\end{array}$ & Olasılık değeri \\
\hline 3372.007 & 3332 & 0.3098 \\
\hline
\end{tabular}

VAR modeli elde edildikten sonra etki-tepki fonksiyonları incelenmiştir. Etki-tepki fonksiyonları, rassal hata terimlerinden birindeki bir standart sapmalık şokun, içsel değişkenlerin şimdiki ve gelecekteki değerlerine olan etkisini yansıtır. VAR analizinde, incelenen değişkenler arasındaki dinamik etkileşimi belirlemede, simetrik ilişkileri tespit etmede, etki-tepki fonksiyonlarının büyük payı vardır. Bir makroekonomik büyüklüğün üzerinde en etkili değişkenin hangisi olduğu varyans ayrıştırması ile etkili bulunan bu değişkenin politika aracı olarak kullanılabilir olup olmadığı ise etki-tepki fonksiyonları ile belirlenir (Özgen ve Güloğlu, 2004). Çalışmaya ilişkin olarak Şekil 3'de yer alan etki-tepki grafikleri yorumlanacak olursa; IAB altın fiyatının Ons fiyatına tepkisi önce pozitif yönde iken, 3.dönemden itibaren azalış gösterip negatif olmakta ve sonra yine az miktarda bir artış ile pozitif olarak ifade edilmektedir. Döviz kurunun ve Ons fiyatının petrol fiyatına karşı gösterdiği tepkiler önce negatif olup daha sonraki dönemlerde pozitiftir. Faiz oranının TÜFE değişkenine karşı tepkisi ise önce pozitif olup 5. dönemden sonra negatif olmaktadır. Ayrıca grafiğe bakıldığında, Ons fiyatındaki bir standart sapmalık şok, en fazla IAB altın fiyatı üzerinden bir tepki yaratırken, petrol fiyatına verilecek şok ise, döviz kuru ve Ons fiyatı tarafından tepki ile karşılanmaktadır. Bu sonuçlar da Granger nedensellik analizinin sonuçlarıyla tutarlıdır.

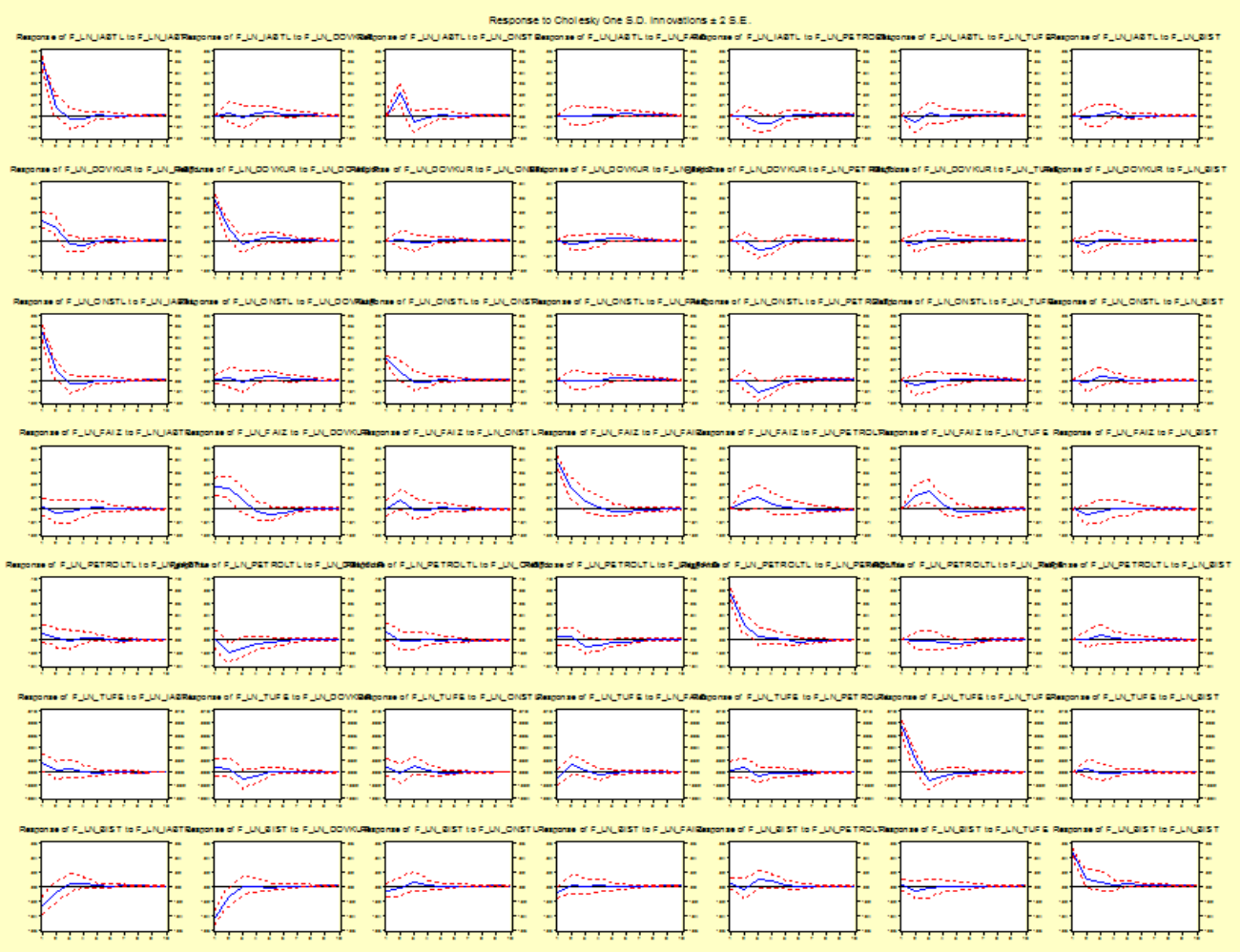

Şekil 3: Etki-Tepki Grafikleri 
Son olarak Tablo 9'daki varyans ayrıştırma analizi sonuçlarına göre, IAB altın fiyatı için gelecek dönem öngörü hata varyansı içinde en büyük paya sahip değişken kendinden sonra yaklaşık \%14'lük pay ile Ons fiyatıdır. İkinci en yüksek paya sahip değişken yaklaşık \%4'lük pay ile petrol fiyatı olurken en düşük paya sahip değişken yaklaşık \%0.2'lik pay ile Faiz oranıdır. Aynı şekilde döviz kuru için gelecek dönem öngörü hata varyansı içinde en büyük paya sahip değişkenler sırasıyla IAB altın fiyatı, Petrol fiyatı, BIST 100 endeksi, faiz oranı, TÜFE ve Ons fiyatıdır. Ons fiyatı için gelecek dönem öngörü hata varyansı içinde en büyük paya sahip değişkenler sırasıyla $I A B$ altın fiyatı, petrol fiyatı, TÜFE, döviz kuru, BIST 100 endeksi ve faiz oranıdır. Faiz oranı için gelecek dönem öngörü hata varyansı içinde en büyük paya sahip değişkenler de sırasıyla döviz kuru, TÜFE, petrol fiyatı, Ons fiyatı, BIST 100 endeksi ve IAB altın fiyatıdır. Petrol fiyatı için gelecek dönem öngörü hata varyansı içinde en büyük paya sahip değişken döviz kuru olurken en düşük paya sahip değişken ise TÜFE'dir. TÜFE ve BIST 100 endeksi için gelecek dönem öngörü hata varyansı içinde en büyük paya sahip değişken ise döviz kurudur. Elde edilen bu sonuçlar Granger nedensellik testinin sonuçlarını destekler niteliktedir.

\section{GENEL DEĞERLENDIRMME VE SONUÇ}

Yatırım aracı olmanın yanı sıra, merkez bankalarının rezervlerinde de hala önemli bir yeri olan altın; endüstri, elektronik, diş̧̧ilik gibi pek çok alanda kullanılan kıymetli bir madendir. Altın fiyatlandırması, serbest piyasa koşullarına göre belirlenmektedir ve altın fiyatı diğer ekonomik değişkenlerden etkilenmektedir. Literatürde dünya altın fiyatlarını etkileyen faktörlere ilişkin olarak yapılan pek çok çalışma bulunmakla birlikte, Türkiye'de altın fiyatlarının incelenmesi sınırlı kalmıştır. Türkiye'deki altın fiyatlarını etkileyen faktörlerin belirlenmesi ile ilgili çalışmaların pek çoğu ise kapsamlı bir ekonometrik analize dayanmamaktadır.

Bu çalışmada, Türkiye'de altın fiyatlarını hangi ekonomik değişkenlerin etkilediği 2005:01-2015:04 dönemi aylık zaman serileri kullanılarak VAR analizi yardımıyla incelenmiştir. Bu amaçla, ülkemiz yatırımcılarının yoğun bir şekilde tercih ettiği altının fiyatını etkileyen yurtiçi faktörler arasından, döviz kuru, ons fiyatı, faiz oranı, petrol fiyatları, TÜFE ve BIST 100 endeksi ele alınmıştır.

$\mathrm{Bu}$ çalışmada öncelikle, incelenen değişkenlere ilişkin tanımlayıcı istatistikler ve korelasyon matrisi oluşturulmuştur. Buna göre, en yüksek değişkenlik $I A B$ altın fiyatında ve Ons fiyatında görülürken, $I A B$ altın fiyatının BIST 100 endeksi ile negatif, diğer değişkenlerle pozitif ilişkili olduğu ortaya çıkmıştır.

Daha sonra sırasıyla birim kök testleri ve eşbütünleşme testleri yapılmıştır. Birim kök testi sonuçlarına göre, düzey değerlerinde durağan olmayan seriler birinci farklarında durağan I(1) hale gelmişlerdir. Eşbütünleşme analizi sonucunda da, IAB altın fiyatı, döviz kuru, ons, faiz oranı, petrol fiyatları, TÜFE ve BIST 100 endeksi değişkenleri arasında uzun dönemli bir ilişkinin bulunmadığı ortaya çıkmıştır. Bu aşamadan sonra, kısa dönemli ilişkilerin varlığını incelemek için VAR modeline dayalı Granger nedensellik testi uygulanmıştır. Ardından etki-tepki grafikleri çizdirilmiş ve varyans ayrıştırma analizi gerçekleştirilmiştir. Analiz sonuçlarına göre, petrol fiyatı Ons fiyatının, Ons fiyatı da $I A B$ altın fiyatının Granger nedenidir, dolayısıyla petrol fiyatları altın fiyatlarını etkilemektedir. TÜFE de faiz oranının Granger nedenidir. Ayrıca petrol ve döviz kuru değişkenleri arasında karşılıklı bir nedensellik ilişkisi mevcuttur.

Çalışmada kullanılan değişkenlerle oluşturulan hata düzeltme modellerinden VAR(2) modelinde değişen varyans ve otokorelasyon sorununun olmadığı görülmüş olup, AR karakteristik polinomunun ters köklerine göre de modelin istikrarlı bir yapıda olduğu ortaya konulmuştur. Son olarak etki-tepki ve varyans ayrıştırma sonuçlarına göre, Ons fiyatındaki bir standart sapmalık şok, en fazla İAB altın fiyatı üzerinden bir tepki yaratırken, petrol fiyatına verilecek şok ise, döviz kuru ve Ons fiyatı tarafından tepki ile karşılanmaktadır. Varyans ayrıştırma analizine göre ise, İA altın fiyatı için gelecek dönem öngörü hata varyansı içinde en büyük paya sahip değişkenler Ons fiyatı ile petrol fiyatı olurken en düşük paya sahip değişken faiz oranıdır. Bu sonuçlar da Granger nedensellik analizinin sonuçlarıyla tutarlıdır. 
Tablo 9: Varyans Ayrıştırması Sonuçları

\begin{tabular}{|c|c|c|c|c|c|c|c|c|}
\hline \multirow[b]{2}{*}{ Dönem } & \multirow[b]{2}{*}{ S.E. } & \multicolumn{7}{|c|}{ İAB Varyans Ayrıştırması } \\
\hline & & İAB & DOVKUR & ONS & FAiz & PETROL & TÜFE & BisT \\
\hline 1 & 0,048349 & 100 & 0 & 0 & 0 & 0 & 0 & 0 \\
\hline 2 & 0,053387 & 84,18144 & 0,22366 & 14,12579 & 0,019491 & 0,04041 & 1,342032 & 0,06717 \\
\hline 3 & 0,054515 & 81,12355 & 0,410024 & 14,76767 & 0,031807 & 2,154255 & 1,445726 & 0,066966 \\
\hline 4 & 0,055374 & 79,03777 & 0,553493 & 14,39482 & 0,038394 & 4,105279 & 1,412878 & 0,457365 \\
\hline 5 & 0,055528 & 78,6056 & 0,863471 & 14,372 & 0,087516 & 4,126928 & 1,405072 & 0,539414 \\
\hline 6 & 0,055592 & 78,4256 & 0,918941 & 14,33912 & 0,177291 & 4,129038 & 1,451877 & 0,558132 \\
\hline 7 & 0,055618 & 78,36501 & 0,928223 & 14,32593 & 0,216288 & 4,12529 & 1,480269 & 0,558989 \\
\hline 8 & 0,055624 & 78,34714 & 0,930098 & 14,32345 & 0,219996 & 4,128544 & 1,490984 & 0,559784 \\
\hline 9 & 0,055626 & 78,34175 & 0,930179 & 14,32267 & 0,220184 & 4,13348 & 1,491604 & 0,560135 \\
\hline \multirow[t]{2}{*}{10} & 0,055627 & 78,33962 & 0,931688 & 14,32231 & 0,220328 & 4,134036 & 1,491898 & 0,56012 \\
\hline & & \multicolumn{7}{|c|}{ Döviz Kuru Varyans Ayrıştırması } \\
\hline Dönem & S.E. & İAB & DOVKUR & ONS & FAiz & PETROL & TÜFE & BisT \\
\hline 1 & 0,030977 & 20,0374 & 79,9626 & 0 & 0 & 0 & 0 & 0 \\
\hline 2 & 0,033497 & 24,14592 & 73,73784 & 0,014397 & 0,362261 & 0,045507 & 0,4823 & 1,211774 \\
\hline 3 & 0,034448 & 23,21746 & 70,33216 & 0,32241 & 0,541811 & 3,927462 & 0,509095 & 1,149609 \\
\hline 4 & 0,035061 & 23,38496 & 67,89609 & 0,401873 & 0,530876 & 5,950487 & 0,671062 & 1,164648 \\
\hline 5 & 0,035187 & 23,24239 & 67,75289 & 0,415941 & 0,743626 & 5,956587 & 0,700185 & 1,188383 \\
\hline 6 & 0,035263 & 23,14598 & 67,57171 & 0,429907 & 0,913097 & 5,979061 & 0,715931 & 1,244307 \\
\hline 7 & 0,035282 & 23,12293 & 67,50737 & 0,430323 & 0,946633 & 5,995193 & 0,745844 & 1,251707 \\
\hline 8 & 0,035286 & 23,1189 & 67,49191 & 0,430233 & 0,947749 & 6,000675 & 0,758899 & 1,251635 \\
\hline 9 & 0,035287 & 23,11811 & 67,48975 & 0,430318 & 0,947944 & 6,003314 & 0,758974 & 1,251582 \\
\hline \multirow[t]{2}{*}{10} & 0,035288 & 23,11742 & 67,48825 & 0,430432 & 0,948808 & 6,003409 & 0,760174 & 1,25151 \\
\hline & & \multicolumn{7}{|c|}{ ONS Varyans Ayrıştırması } \\
\hline Dönem & S.E. & İAB & DOVKUR & ONS & FAiz & PETROL & TÜFE & BisT \\
\hline 1 & 0,047271 & 83,72683 & 0,020475 & 16,2527 & 0 & 0 & 0 & 0 \\
\hline 2 & 0,048939 & 81,17697 & 0,166555 & 17,46711 & 0,002416 & 0,033208 & 1,029491 & 0,124252 \\
\hline 3 & 0,050467 & 76,83223 & 0,316032 & 16,54841 & 0,043747 & 4,754955 & 1,107378 & 0,397246 \\
\hline 4 & 0,051153 & 75,06776 & 0,559674 & 16,25217 & 0,046901 & 6,52202 & 1,077862 & 0,473612 \\
\hline 5 & 0,051321 & 74,57943 & 0,966733 & 16,16254 & 0,151231 & 6,562594 & 1,08431 & 0,493163 \\
\hline 6 & 0,051408 & 74,33016 & 1,059684 & 16,10799 & 0,296325 & 6,542458 & 1,138171 & 0,525213 \\
\hline 7 & 0,051443 & 74,24268 & 1,075306 & 16,08694 & 0,346193 & 6,536245 & 1,184673 & 0,52796 \\
\hline 8 & 0,051453 & 74,21458 & 1,077262 & 16,08118 & 0,353524 & 6,542326 & 1,201574 & 0,529552 \\
\hline 9 & 0,051455 & 74,20834 & 1,077584 & 16,0802 & 0,35381 & 6,548033 & 1,202223 & 0,52981 \\
\hline \multirow[t]{2}{*}{10} & 0,051456 & 74,2053 & 1,07966 & 16,07962 & 0,354158 & 6,548824 & 1,202648 & 0,529795 \\
\hline & & \multicolumn{7}{|c|}{ FAiz Varyans Ayrıştırması } \\
\hline Dönem & S.E. & İAB & DOVKUR & ONS & FAiz & PETROL & TÜFE & BiST \\
\hline 1 & 0,041476 & 0,153658 & 19,50956 & 0,053587 & 80,28319 & 0 & 0 & 0 \\
\hline 2 & 0,050179 & 0,403527 & 24,83725 & 2,293809 & 65,34156 & 1,461689 & 4,823573 & 0,838601 \\
\hline 3 & 0,053833 & 0,481875 & 23,35684 & 1,996289 & 57,89906 & 4,240909 & 11,16698 & 0,858046 \\
\hline 4 & 0,054176 & 0,476148 & 23,12651 & 1,988375 & 57,30012 & 4,728313 & 11,52442 & 0,856109 \\
\hline 5 & 0,054423 & 0,523746 & 23,43116 & 2,0809 & 56,84896 & 4,755089 & 11,51163 & 0,84851 \\
\hline 6 & 0,054562 & 0,540979 & 23,54449 & 2,078446 & 56,68993 & 4,74197 & 11,55751 & 0,846682 \\
\hline 7 & 0,054607 & 0,542721 & 23,53584 & 2,078015 & 56,64313 & 4,740432 & 11,60377 & 0,856095 \\
\hline 8 & 0,05462 & 0,543396 & 23,52468 & 2,077929 & 56,62785 & 4,749465 & 11,61865 & 0,858026 \\
\hline 9 & 0,054622 & 0,543354 & 23,52437 & 2,078315 & 56,62419 & 4,753238 & 11,61842 & 0,858111 \\
\hline \multirow[t]{2}{*}{10} & 0,054623 & 0,543696 & 23,52489 & 2,078553 & 56,62201 & 4,754424 & 11,61835 & 0,85808 \\
\hline & & \multicolumn{7}{|c|}{ PETROL Varyans Ayrıştırması } \\
\hline Dönem & S.E. & İAB & DOVKUR & ONS & FAiz & PETROL & TÜFE & BisT \\
\hline 1 & 0,075274 & 1,713946 & 0,023689 & 2,873447 & 0,389924 & 94,999 & 0 & 0 \\
\hline 2 & 0,082115 & 1,539119 & 6,31841 & 2,476396 & 0,662683 & 88,9558 & 0,047379 & 0,000209 \\
\hline
\end{tabular}




\begin{tabular}{|c|c|c|c|c|c|c|c|c|}
\hline 3 & 0,084403 & 1,463888 & 8,20127 & 2,408184 & 2,05927 & 84,75043 & 0,055607 & 1,061353 \\
\hline 4 & 0,085378 & 1,631313 & 8,441549 & 2,374323 & 3,039521 & 83,00515 & 0,32133 & 1,186819 \\
\hline 5 & 0,085926 & 1,757096 & 8,656331 & 2,356293 & 3,317358 & 81,95059 & 0,738257 & 1,22408 \\
\hline 6 & 0,086131 & 1,750661 & 8,689331 & 2,345661 & 3,398348 & 81,65828 & 0,907026 & 1,250694 \\
\hline 7 & 0,086166 & 1,751579 & 8,683588 & 2,347767 & 3,407897 & 81,63998 & 0,913779 & 1,25541 \\
\hline 8 & 0,086179 & 1,752229 & 8,696062 & 2,349006 & 3,408538 & 81,62451 & 0,914136 & 1,255522 \\
\hline 9 & 0,086185 & 1,752326 & 8,701606 & 2,348644 & 3,413177 & 81,61241 & 0,916256 & 1,255583 \\
\hline 10 & 0,086189 & 1,752524 & 8,702334 & 2,348522 & 3,415473 & 81,60643 & 0,918954 & 1,255762 \\
\hline & & \multicolumn{7}{|c|}{ TÜFE Varyans Ayrıştırması } \\
\hline Dönem & S.E. & İAB & DOVKUR & ONS & FAiz & PETROL & TÜFE & BisT \\
\hline 1 & 0,00762 & 3,623422 & 1,224599 & 1,186998 & 1,060183 & 0,256296 & 92,6485 & 0 \\
\hline 2 & 0,008018 & 3,39073 & 1,7046 & 1,133633 & 3,140849 & 1,038607 & 89,0221 & 0,569481 \\
\hline 3 & 0,008314 & 3,626739 & 3,409078 & 2,62043 & 3,088178 & 1,329002 & 85,37123 & 0,555344 \\
\hline 4 & 0,008376 & 3,578057 & 3,926457 & 2,697821 & 3,359983 & 1,368849 & 84,51749 & 0,551346 \\
\hline 5 & 0,008385 & 3,593383 & 3,929141 & 2,734908 & 3,387513 & 1,417389 & 84,35346 & 0,584209 \\
\hline 6 & 0,008389 & 3,590504 & 3,977472 & 2,74393 & 3,384229 & 1,443866 & 84,2751 & 0,584899 \\
\hline 7 & 0,00839 & 3,590174 & 3,988443 & 2,74405 & 3,384811 & 1,445667 & 84,26052 & 0,586331 \\
\hline 8 & 0,008391 & 3,591638 & 3,989603 & 2,744066 & 3,387273 & 1,445593 & 84,25526 & 0,586569 \\
\hline 9 & 0,008391 & 3,592401 & 3,989991 & 2,743903 & 3,389264 & 1,445509 & 84,2524 & 0,586533 \\
\hline \multirow[t]{2}{*}{10} & 0,008391 & 3,592347 & 3,990011 & 2,744079 & 3,389664 & 1,445909 & 84,25132 & 0,586674 \\
\hline & & \multicolumn{7}{|c|}{ BiST Varyans Ayrıştırması } \\
\hline Dönem & S.E. & İAB & DOVKUR & ONS & FAiz & PETROL & TÜFE & BiST \\
\hline 1 & 0,069321 & 15,97105 & 37,51881 & 0,815813 & 1,624284 & 0,145483 & 0,038322 & 43,88624 \\
\hline 2 & 0,072786 & 15,88321 & 38,64355 & 0,885129 & 1,50611 & 0,591104 & 0,990509 & 41,50038 \\
\hline 3 & 0,073841 & 15,68414 & 37,55132 & 1,479078 & 1,501047 & 1,808772 & 1,164477 & 40,81117 \\
\hline 4 & 0,074211 & 15,76069 & 37,17929 & 1,465026 & 1,486203 & 2,521825 & 1,180569 & 40,4064 \\
\hline 5 & 0,074292 & 15,72828 & 37,1738 & 1,473249 & 1,515075 & 2,51896 & 1,18697 & 40,40366 \\
\hline 6 & 0,074329 & 15,71269 & 37,15751 & 1,472317 & 1,557586 & 2,527789 & 1,189326 & 40,38279 \\
\hline 7 & 0,074338 & 15,70972 & 37,15219 & 1,4722 & 1,565328 & 2,529936 & 1,192932 & 40,37769 \\
\hline 8 & 0,07434 & 15,70881 & 37,15 & 1,472104 & 1,565346 & 2,531971 & 1,196393 & 40,37537 \\
\hline 9 & 0,074341 & 15,70869 & 37,1497 & 1,472089 & 1,56535 & 2,53275 & 1,196491 & 40,37493 \\
\hline 10 & 0,074341 & 15,70862 & 37,14981 & 1,472101 & 1,565504 & 2,532775 & 1,196741 & 40,37445 \\
\hline
\end{tabular}

\section{KAYNAKÇA}

Aksoy, M. ve Topçu, N. (2013) "Altın ile Hisse Senedi ve Enflasyon Arasındaki Illişki" Atatürk Üniversitesi Iktisadi ve Idari Bilimler Dergisi, 27 (1): 59-78.

Cılız, C. (2010) "Ülke Altın Rezerv Oranlarını Etkileyen Faktörlerin Kantitatif Olarak Analiz Edilmesi" (Yayınlanmamış Doktora Tezi), Kadir Has Üniversitesi Sosyal Bilimler Enstitüsü, İstanbul.

Duyar, M. (2010) "Altın Arzını Etkileyen Faktörlerin Oluşan Fiyatlar Üzerindeki Etkisi" Uluslararası Sosyal Araştırmalar Dergisi, 3 (14):214-225.

Elmas, B. ve Polat, M. (2013) "Gümüş Fiyatları ve Dow Jones Endeksi'nin Altın Fiyatlarına Etkisi Üzerine Eşbütünleşme ve Nedensellik Analizi" Bingöl Üniversitesi Sosyal Bilimler Enstitüsü Dergisi, Yıl: 3/ Cilt: 3/ Sayı:6.
Elmas, B. ve Polat, M. "Altın Fiyatlarını Etkileyen Talep Yönlü Faktörlerin Tespiti: 1988-2013 Dönemi" C.Ü. iktisadi ve Idari Bilimler Dergisi, Cilt 15, Sayı 1.

Engle, R.F. ve Granger, C.W.J., (1987) "Co-integration and Error Correction: Representation, Estimation, and Testing" Econometrica, 55(2):251-76.

Fuller, W.A., (1996) "Introduction to Statistical Time Series" 2nd edition, John Wiley and Sons Inc.

Gacener, A. (2005) "Türkiye Açısından Wagner Kanunu'nun Geçerliliğinin Analizi" Dokuz Eylül Üniversitesi, Iktisadi ve Idari Bilimler Fakültesi Dergisi, 20 (1):103-122.

Gökdemir, L. ve Ergün, S. (2007) "Altın Fiyatlarındaki İstikrarsızlığın Altın Ticareti Üzerindeki Etkisi: Türkiye Örneği" Journal of Yasar University, 2 (5): 461-476. 
Johansen, S. (1988) "Statistical Analysis of Cointegration Vectors" Journal of Economic Dynamics and Control, 12(2-3):231-54.

Johansen, S., (1995) "Likelihood Based Inference in Cointegrated vector Autoregressive Models" Oxford: Oxford University Press.

Karataş, T. ve Ürkmez, E. (2013) “Küresel Kriz Sürecinde Altın Fiyatlarını Etkileyen Dinamikler Dynamics Affecting Gold Prices in the Global Crisis" International Conference on Eurasian Economies.

Kutlar, A. (2007) "Ekonometriye Giriş", Nobel Yayınları, Ankara.

Kültürcü, A. (2014) "Yatırım Aracı Olarak Altın ve Türkiye'deki Altın Piyasaları" (Yüksek Lisans Tezi), İstanbul Ticaret Üniversitesi Sosyal Bilimler Enstitüsü, İstanbul.

Özçicek, Ö. ve McMillin, D. (1999)“Lag Length Selection in Vector Autoregressive Models: Symmetric and Asymmetric Lags" Applied Economics, 31: 517-524.

Özgen, F. ve Güloğlu, B. (2004) “Türkiye'de İç Borçların İktisadi Etkilerinin VAR Tekniği ile Analizi" ODTU Geliştirme Dergisi, 31: 93-114.

Phillips, P.C.B. ve Perron, P; (1988), Testing for a Unit Root in Time Series Regressions, Biometrika, 75: 335346.

Poyraz, E. ve Didin S. (2008) "Altın Fiyatlarındaki Değişimin Döviz Kuru, Döviz Rezervi ve Petrol Fiyatlarından Etkilenme Derecelerinin Çoklu Faktör Modeli İle Değerlendirilmesi" Süleyman Demirel Üniversitesi Iktisadi ve Idari Bilimler Fakültesi Dergisi, 13(2): 93-104.

Selvanathan, S. ve Selvanathan, E.A. (1999) "The Effect of The Price of Gold on Its Production: A Time-Series Analysis" Resources Policy, 25: 265275.

Soytas, U. ve Sari, R., Hammoudehb, S., Hacihasanoglu, E. (2009) "World Oil Prices, Precious Metal Prices and
Macroeconomy in Turkey" Energy Policy, 37: 55575566.

Tarı, R., (2012) "Ekonometri", Umuttepe Kitapevi, 8.Baskı, Kocaeli.

Taşçı, F.I. (2010) “Ekonometrik Bir Yaklaşımla Altın Piyasasının İncelenmesi, (Yayınlanmamış Yüksek Lisans Tezi)" Gazi Üniversitesi Sosyal Bilimler Enstitüsü, Ankara.

Topçu, A. (2010) "Altın Fiyatlarını Etkileyen Faktörler", Sermaye Piyasası Araştırma Kurulu

Araştırma Raporu, Ocak.

Toraman, C., Başarır, Ç. ve Bayramoğlu, M.F. (2011) "Altın Fiyatlarını Etkileyen Faktörlerin Tespiti Üzerine: MGARCH Modeli ile bir İnceleme", Uluslararası Alanya Işletme Fakültesi Dergisi, 3 (1): 1-20.

Vural, M. G. (2003) "Altın Piyasası ve Altın Fiyatlarını Etkileyen Faktörler, (Yayınlanmamış Uzmanlık Yeterlilik Tezi)" Türkiye Cumhuriyeti Merkez Bankası Piyasalar Genel Müdürlüğü, Ankara.

Yıldız, A. (2014) “BIST 100 Endeksi ile Alternatif Yatırım Araçlarının İlişkisi" Süleyman Demirel Üniversitesi Iktisadi ve Idari Bilimler Fakültesi Dergisi, C.19, S.2, 3956.

Yıldız Contuk, F. ve Burucu, H., Güngör, B. (2013) "Effect of Gold Price Volatility on Stock Returns: Example of Turkey" International Journal of Economics and Finance Studies, 5(1):1309-8055 (Online).

http://borsanasiloynanir.co/altin-fiyatlari-nedenduser-yukselir/

http://www.bigpara.com/bigpara-uzmanlari/sevinekinci/altin-petrol-fiyatlari-korelasyonu_ID965958

h t t p : / / w w w.t c m b.gov.t r/w p s / w c m / connect/190faaac-0065-48a4-8550-cfdd698abf02/ Doviz-Rezerv-Yonetimi.pdf?MOD=AJPERES 